\title{
Chitinase activity potential and identification of chitinolytic bacteria isolated of swimmer crab's cell
}

\author{
Rieny Sulistijowati ${ }^{*}$, Sudin, Rita Marsuci Harmain \\ (Department of Fishery Product Technology, Faculty of Fishery and Marine Science, Universitas Negeri Gorontalo, \\ Central City of Gorontalo, 96128, Indonesia)
}

\begin{abstract}
This study aimed at investigating the chitinase enzyme activity produced by chitinolytic bacteria from the skin of blue swimmer crab (Portunus pelagicus) and identification of the genus isolate. This study consists of two stages: firstly, the qualitative and quantitative activity of the chitinase enzyme; and secondly, biochemical identification of the bacteria. The quantitative chitinase enzyme activity is measured using the UV-Vis spectrophotometer UV-Vis at the wavelength at $660 \mathrm{~nm}$. The chitinase enzyme is obtained from the isolation of chitinolytic bacteria cultured within a media to grow solid chitin, which contains colloidal chitin substrate as chitinase inductor at the temperature of $30^{\circ} \mathrm{C}$. The highest chitinolytic activity is obtained from the $24 \mathrm{~h}$ supernatant culture, with a value of enzyme activity at $0.149 \mathrm{U} / \mathrm{mL}$. Macroscopic and microscopic identification showed that the chitinolytic bacteria isolate R1, whereas the biochemical cell shows the characteristics of the genus Pseudomonas.
\end{abstract}

Keywords: biodegradable, chitinase, spectrophotometer, Portunus pelagicus, Pseudomonas DOI: $10.25165 /$ j.ijabe.20211403.5273

Citation: Sulistijowati R, Sudin, Harmain R M. Chitinase activity potential and identification of chitinolytic bacteria isolated of swimmer crab's cell. Int J Agric \& Biol Eng, 2021; 14(3): 228-231.

\section{Introduction}

The earth chitin is among the most abundant biomass present. Chitinase plays an important role in the decomposition of chitin and potentially in the utilization of chitin as a renewable resource. The implementation of biotechnology toward chitin, which keeps progressing, is the utilization of enzymes from microorganisms for biodegradation. In biodegradation, an enzyme derived from microorganisms breaks large molecule or chitin polymer into utilizable products. In general, types of an enzyme that degraded the chitin are chitinase enzyme ${ }^{[1]}$.

Microorganisms that degraded chitin, in general, are those derived from bacteria group. Chitinase enzyme produced by chitinolytic bacteria has the potential to degrade chitin due to the existence of the chitinase enzyme, which enables the conversion of abundantly available chitin into usable products. The bacteria that produce chitinase enzyme or chitinolytic bacteria can be found within the habitat that contains a high level of chitin, such as in the cell of the blue swimmer crab. Blue swimmer crab's cell (Portunus pelagicus) can be obtained from the processing waste or fresh. Chitinase enzyme application can be informed of enzymatic production of chitin. The chitin can be produced enzymatically and chemically. The enzymatic method uses enzymes or bacteria for deproteinization by adding enzyme or by the involvement of chitinase to degrade chitin. Meanwhile, the chemical process is through demineralization by adding acid or

\section{Received date: $2019-12-25 \quad$ Accepted date: $2020-06-29$}

Biographies: Sudin, Junior Scientist, research interest: marine biotechnology, Email: sudynsultra@gmail.com; Rita Marsuci Harmain, Research Assistant, research interest: marine microbiology, Email: rmarsuci@yahoo.com.

*Corresponding author: Rieny Sulistijowati, Associate Professor, research interest: biotechnology process. Department of Fishery Product Technology, Faculty of Fishery and Marine Science, Universitas Negeri Gorontalo, Indonesia, Central City of Gorontalo, Sudirman Street No. 06, Postal Code 96128. Tel: +62-435-821125, Email: rienysulistijowati@ung.ac.id. alkali, such as $\mathrm{HCl}$ and $\mathrm{NaOH}^{[2]}$.

Arbia et al. ${ }^{[3]}$ isolate chitinolytic bacteria to produce several bacteria, one of which was Pseudomonas aeruginosa bacteria isolated from crab's cell. The production of chitinase enzyme from Aspergillus niger utilized the blue swimmer crab's waste as inducer $^{[4]}$. Protease produced by Pseudomonas aeruginosa K-187, the highest protease activity was as high as $21.2 \mathrm{U} / \mathrm{mL}, 10$-fold that $(2.2 \mathrm{U} / \mathrm{mL})$ obtained before optimization ${ }^{[5]}$. In common with all enzymes, external factors such as temperature, $\mathrm{pH}$ and type of media are important for the activity, catalytic efficiency, stability and proper functioning of proteases ${ }^{[6]}$. Chitinase activity of isolates chitinolytic bacteria can degrade different chitins.

The needs for the chitin derivatives are increasing. Thus, researches on chitinase enzyme activity through the isolation of bacteria from the blue swimmer crab is needed. Two isolates chitinolytic bacteria from the skin of blue swimmer crab were observed primarily in Katialada village of Kwandang sub-district of North Gorontalo Regency, Gorontalo Province of Indonesia. The results obtained from the purification process following $48 \mathrm{~h}$ incubation in the temperature of $30^{\circ} \mathrm{C}$ shows a clear zone that formed in the colony of the bacteria ${ }^{[7]}$. However, specific zones are only found in white and light brown-colored bacteria.

Furthermore, these two isolates are macroscopically and microscopically identified. The R1 isolate shows a white-colored colony; meanwhile, the R2 isolate shows a light brown-colored colony. Meanwhile, from the shape/form and elevation of the colony, there are no differences between isolates R1 and R2, both colonies have a circular shape and convex elevation. The result of gram staining in these two chitinolytic bacteria isolates R1 and R2 shows the gram-negative result. This is signified by changes of color of these two isolates into the red after the gram staining. The study shows that CI 11 of the R1 isolate has the largest Chitinolytic Index by one, the chitinolytic index shows the ability of the microbes to degrade chitin. The more enzyme produced, the wider the clear zone produced as more chitin is degraded. 
This is due to the type of bacteria growth pattern and enzyme activity needs to be known to have a good degrading ability. Therefore, this study aimed at testing the produced chitinase activity and identification chitinase producer bacteria of blue swimmer crab.

\section{Methods and materials}

\subsection{Station and laboratory}

Isolate R1 was obtained from fresh blue swimmer crab's cells which came from the crabs' farmer in Katialada village of Kwandang sub-district of North Gorontalo Regency, Gorontalo Province of Indonesia. The identification biochemical test of the chitinolytic bacteria were carried out at the Fish Quarantine Station Laboratory Quality Control and Fisheries Product Security Class I Gorontalo Province of Indonesia, and the chitinolytic bacteria enzyme activity test are carried out at the Pharmaceutical Laboratory of Universitas Negeri Gorontalo.

\subsection{Materials}

The tools used in this study were test tube, inoculum needle, vortex, measuring cup, beaker glass, Erlenmeyer, centrifuge, centrifuge tube, shaker, $\mathrm{pH}$ meter, micropipette, micro tip, stirrer, magnetic stabilizer, petri dish, oven, crooked spoon, Bunsen lamp, incubator, laminar air, analytical scales, UV-vis spectrophotometer, and microscope.

Materials used in this study were R1 isolated of blue swimmer crab's cell, chitin, chitin colloidal (chitin, condensed $\mathrm{HCl}, \mathrm{NaOH}$, distillate water), chitin agar (chitin colloidal, $\mathrm{KH}_{2} \mathrm{PO}_{4}$, $\mathrm{MgSO}_{4} \cdot 7 \mathrm{H}_{2} \mathrm{O}$, yeast extract, agar, distillate water), Luria broth (yeast extract, tryptone water, $\mathrm{NaCl}$, distillate water), nutrient agar, aluminum foil, alcohol, crystal violet, iodine solution, glucose, sucrose, lactose, maltose, mannitol, triple sugar iron agar, motility indole ornithine, oxidative/fermentative, methyl red-Voges Proskauer, methyl-red, and sterile liquid paraffin.

\subsection{Quantitative activity of chitinase enzyme test}

One dose of inoculum was added into $100 \mathrm{~mL}$ of production medium (similar composition to a solid medium, but without agar) then incubated in the temperature of $30^{\circ} \mathrm{C}$ and centrifuged in the speed of $170 \mathrm{r} / \mathrm{min}$. Every three hours, $2 \mathrm{~mL}$ of cell culture was sampled for $33 \mathrm{~h}$. Then centrifuged in the temperature of $4^{\circ} \mathrm{C}$ using $10.000 \mathrm{r} / \mathrm{min}$ speed for $10 \mathrm{~min}$, the formed supernatant was the raw extract of chitinase enzyme. The absorbance is then measured using spectrophotometer UV/Vis in wavelength of $660 \mathrm{~nm}^{[8]}$, the sample was carried out twice repetitions.

\subsection{Biochemical test}

The biochemical test was carried out to identify and classify bacteria into their group of taxonomy. The principle of this biochemical test is that if the bacteria are cultured in several media, the bacteria show macroscopic differences in their growth ${ }^{[9,10]}$. Carbohydrate fermentation test was to find out the bacteria's ability in fermenting carbohydrate by preparing the carbohydrate broth which consists of glucose, sucrose, maltose, and mannitol; MR-VP (methyl red-Voges Proskauer) test was to inoculate bacteria into a medium, which incubated in the temperature of $30^{\circ} \mathrm{C}$ for $24 \mathrm{~h}$ by adding methyl red reagent and $\mathrm{KOH}$, to observe the bacteria ability in producing the mix acid and acetylenes; Citrate test was inoculating bacteria into a medium and incubated in the temperature of $30^{\circ} \mathrm{C}$ for $24 \mathrm{~h}$ by adding bromothymol blue (BTB) reagent, then the ability of the bacteria to use citrate as the only source of carbon was observed; $\mathrm{H}_{2} \mathrm{~S}$ test was to inoculate the bacteria into sulfide indole motility (SIM) which incubated for 24-48 $\mathrm{h}$ in the temperature of $30^{\circ} \mathrm{C}$, then the ability of the bacteria to produce $\mathrm{H}_{2} \mathrm{~S}$ which signified by the existence of black sediment was observed; Oxidation/fermentation $(\mathrm{O} / \mathrm{F})$ test was inoculating the bacteria into the $\mathrm{O} / \mathrm{F}$ medium, which incubated for $24 \mathrm{~h}$ in the temperature of $30^{\circ} \mathrm{C}$, then observe the ability of the bacteria to use carbohydrate through fermentation or oxidation; TSIA (triple sugar iron agar) test was inoculating bacteria into TSIA media, which incubated for $24-48 \mathrm{~h}$ in the temperature of $30^{\circ} \mathrm{C}$, then the ability of the bacteria in fermenting glucose, lactose, and sucrose was observed; Indole test was inoculating bacteria into indole media, which incubated for $24 \mathrm{~h}$ in the temperature of $30^{\circ} \mathrm{C}$, then the ability of bacteria in degrading the tryptophan amino acid in the medium was observed.

\section{Results and discussion}

\subsection{Quantitative activity of the chitinolytic bacteria enzyme}

The activity of the chitinolytic bacteria enzyme is essential to be known to find out the ability of the bacteria to produce the enzyme in $33 \mathrm{~h}$ with an interval of $3 \mathrm{~h}$. As shown in Figure 1, there were several increasing and decreasing stages in chitinase activity. The first inclination happened during the incubation time of 0 to $12 \mathrm{~h}$. The second increase of the enzyme activity showed that the substrate was starting to be hydrolyzed to produce the chitinase enzyme. Hence, bacteria could digest nutrition. Patil et al. ${ }^{[11]}$ found that bacteria produce extracellular chitinase to take on nutrition. Following this inclination, there is the first declining phase on the $15^{\text {th }}$ to the $18^{\text {th }}$ hour of incubation. The decrease of this enzyme activity is due to other compounds (aside from N-Acetyl glucosamine) that triggers the decrease of enzyme production.

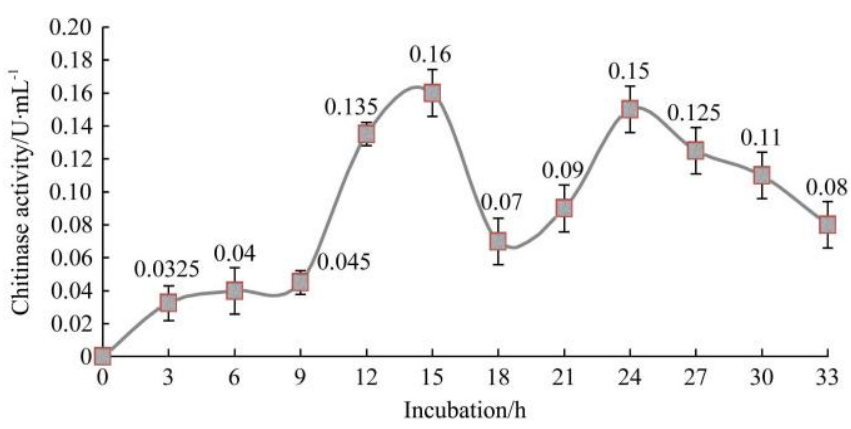

Figure 1 Chitinase activity curve from Pseudomonas

This phenomenon is due to the existence of other chitin-degrading enzymes produced by the bacteria. Colloidal chitin also can be hydrolyzed by deacetylating chitin produced by chitosan and chitosanase which produce chitobiose ${ }^{[12]}$. Following this declining phase, the chitinase activity climbs up in the incubation time of the $21^{\text {st }}$ hour to its highest chitinase activity can be obtained from the supernatant culture in the incubation of time of the $24^{\text {th }}$ hour, which stated with the value of enzyme activity of $0.149 \mathrm{U} / \mathrm{mL}$. One unit of chitinase enzyme activity is defined as several enzymes needed to release $1 \mathrm{mmol} \mathrm{NAG/min}$. This result is different from the result of the enzymes activity test carried out by Purkan et al. ${ }^{[8]}$ who found that the highest enzyme activity was in the $18^{\text {th }}$ hour of incubation time, which stated with the value of enzyme activity of $0.3850 \mathrm{U} / \mathrm{mL}$. Moreover the ability of the bacteria to produce chitinase highly varied. Factors such as different types of bacteria, the growth rate of each isolate in the medium, temperature, $\mathrm{pH}$ or laboratory treatment during the experiment can be factors that influence variation in the produced enzyme activity ${ }^{[13,14]}$. Chitinase activity was 0.213 and $0.219 \mathrm{U} / \mathrm{mL}$ respectively of PBK 2 and SA 1.2 isolates from shrimp waste. Based on 16S rDNA sequences, isolate of PBK 2 was identified as Acinetobacter 
johnsonii 3-1, whereas SA 1.2 was identified as Bacillus amyloliquefaciens GR53 with $99.78 \%$ similarity ${ }^{[15]}$.

The rebound of enzyme activity shows that there is more of the substrate being hydrolyzed. The chitinase enzyme activity is steadily increasing until it reaches optimum incubation time. Following the reach of this optimum incubation time, the enzyme activity decreases due to the accumulation of hydrolyzed products, which can further inhibit the enzyme activity. This is characterized by the decrease of enzyme activity on the incubation time of hour 27 to hour 33 . The decrease of chitinase enzyme activity after the optimum incubation time is due to the changes in the state of the enzyme ion and the state of substrate ion which caused denaturation of enzyme which followed by the loose of enzyme catalytic activity ${ }^{[12]}$. Besides, there are also change in the tertiary structure of the enzyme due to denaturation, which made the hydrophobic amino acid group within the enzyme come into contact with water, thus, the solubility of the enzyme weakens. The decrease of chitinase solubility causes a gradual decrease in enzyme activity.

Chitinolytic bacteria isolates showed unstable chitinase activity (fluctuate). This may be due to the isolate that produces the chitinase at the beginning of its growth ${ }^{[13]}$. In line with the utilization of nutrition for growth, it is also suspected that chitinase is also used by bacteria as a source of protein, thus its chitinase activity decreases.

The decrease of enzyme activity can also be caused by factors such as temperature, $\mathrm{pH}$, substrate and biomass during treatment in the laboratory. The temperature has two main influences on the reaction and the denaturation. The influence of reaction toward the enzyme is that the increase of temperature will accelerate the reaction process, while the decrease in the temperature will cause the reaction to slow down. When the temperature reaches a certain limit, it will cause denaturation. Besides, when the $\mathrm{pH}$ of the environment is too acid or base, enzyme denaturation can also happen. Reaction speed catalyzed by the enzyme is highly influenced by substrate concentration. In the low level of substrate concentration, reaction speed by catalyzed by the enzyme can also be very low. In reverse, reaction speed will increase along with the increase of substrate concentrate up to certain points that is the maximum reaction speed limit. When this saturated point of the enzyme has been reached, it will not function properly. Lastly, the number of bacteria inoculum (biomass) inserted into the media also strongly influence the enzyme activity.

\subsection{Biochemical test}

The biochemical test toward the characteristics of chitinolytic bacteria was carried out by fermenting bacteria in the various sources of nutrition as shown in Figure 2. The biochemical test result of chitinolytic bacteria is presented in Table 1 .

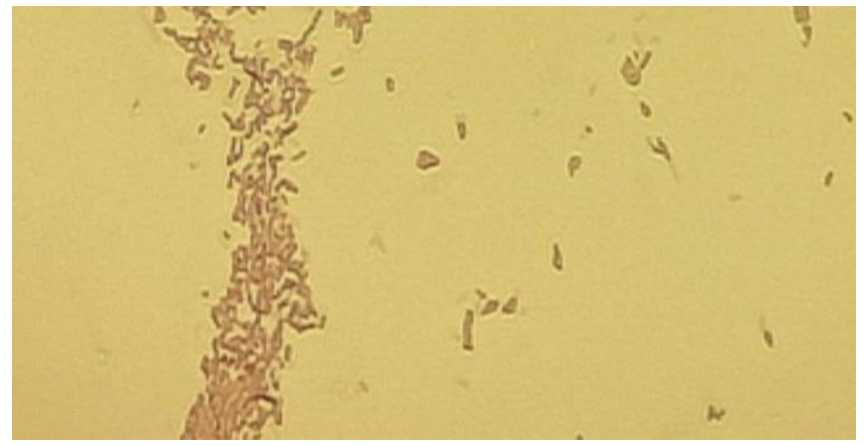

Figure 2 Isolate R1 (10×100 magnification)
Table 1 Biochemical characteristics of chitinolytic bacteria isolate $\mathbf{R} 1$

\begin{tabular}{ccc}
\hline No & Test & Results \\
\hline 1 & Glucose fermentation & Negative \\
2 & Sucrose fermentation & Negative \\
3 & Lactose fermentation & Negative \\
4 & Maltose fermentation & Negative \\
5 & Mannitol fermentation & Negative \\
6 & Citrate use & Negative \\
7 & Sulfide indole motility & Negative \\
8 & Triple sugar iron agar & Alkaline/Alkaline \\
9 & Methyl red reaction & Negative \\
10 & Voges Proskauer reaction & Negative \\
11 & Indole production & Negative \\
12 & Oxidase/Fermentative action & Negative \\
\hline
\end{tabular}

Fermentation test in several types of carbohydrate (glucose, maltose, sucrose, mannitol, lactose) shows that all fermentation reaction is negative. This is characterized by the unchanging red color of the carbohydrate media. When the color of the medium in the carbohydrate test turns into yellow, it means that the colony forms acid from that carbohydrate ${ }^{[10]}$.

A citrate test was carried out to find out the ability of the chitinolytic bacteria isolates to utilize citrate as the only source of carbon and energy. When a microorganism can use citrate, there will be an increase of $\mathrm{pH}$ and change in the color of the media into blue color. In this study, the citrate test reveals that the chitinolytic bacteria cannot utilize citrate as the only source of carbon. This is shown by the unchanging green color of the media, which means that the test result is negative. Positive test results in the citrate test are shown when the color changes from green to blue ${ }^{[16]}$.

Further, the $\mathrm{H}_{2} \mathrm{~S}$ test result in SIM is negative. This negative result is reached when microorganism has no ability to hydrolyzed heavy metal within the media. $\mathrm{H}_{2} \mathrm{~S}$ is produced by several types of microorganisms, which can break or degrade amino acid within the sulfur ( $\mathrm{S}$ ). The existence of $\mathrm{H}_{2} \mathrm{~S}$ can be observed by adding several crystals of heavy metals into the media.

The reaction observable in the TSIA test shows a red color, which means that there is no change of color in both vertical and slight agar. This indicates that the bacteria are unable to ferment sugar. In the vertical agar if the bacteria can ferment glucose, the color of the media will change from red to yellow ${ }^{[17]}$. Whereas in slight agar, if the bacteria can ferment lactose and sucrose, the color of the media will change into yellow, meanwhile, when there is no fermentation process of lactose and sucrose, the color will not change.

Methyl red test also reveals a negative result. This is shown by the unchanging color of the media which does not change into yellow even after the addition of methyl red reagent. The red colour signifies the positive test result, and if the color of the broth is yellow, then the result of the test is negative ${ }^{[16]}$. Similarly, the Voges Proskauer test also shows a negative result. This is evident after the addition of the $\mathrm{KOH}$ solution; the color does not change. The Voges Proskauer test will be stated as positive when there is a form of acid, which signifies by the changes of medium color into pink after the $\mathrm{KOH}$ solution is added. Meanwhile, the indole test also shows a negative result. This result is obtained after the reagent Kovac is added, which signify by the formation of a yellow ring. The existence of indole is detected by Kovac reagent and the formation of a red ring. 
The objective of the oxidizing fermentative test is to find out the oxidation and fermentation characteristics of bacteria toward glucose. Based on the result of the study on the O/F test, it does not show either oxidation or fermentation. This is evident when the media, either without liquid paraffin or without paraffin at all, do not change color. Bacteria are said to be fermentative when both inoculated media change color into yellow. Bacteria are oxidative when tube sealed with no paraffin changes color into yellow and the tube sealed with paraffin does not change color ${ }^{[18]}$.

The morphology test result (macroscopic and microscopic tests) of chitinolytic bacteria have bar cell and gram-negative ${ }^{[9]}$. The biochemical test of the chitinolytic bacteria consists of carbohydrate, citrate, sulfide indole motility, triple sugar iron agar, $\mathrm{MR}-\mathrm{VP}$, indole and $\mathrm{O} / \mathrm{F}$ test should obtain negative results as indicators of a genus of Pseudomonas. Several studies to determine chitinolytic bacteria from the genus of Pseudomonas ${ }^{[4]}$ that utilized blue swimmer crab's waste as an inducer to the production of chitinase enzyme from Aspergillus niger. A study by Arbia et al. ${ }^{[3]}$ isolated chitinolytic bacteria to produce several bacteria, one of which was Pseudomonas aeruginosa bacteria isolated from crab's cell. Genus Pseudomonas generally has bar cell shape and gram-negative. A study by Wang et al. ${ }^{[19]}$ isolated Pseudomonas aeruginosa K-187 known produced two bifungtional chitinase and lysozyme. Thompson et al. ${ }^{[20]}$ found that Pseudomonas aeruginosa strain 385 produced chitinase antigen.

\section{Conclusions}

This study concludes chitinolytic bacteria isolated from blue swimmer crab's cell (Portunus pelagicus) genus of Pseudomonas. The highest chitinase activity was obtained from the supernatant culture in the $24^{\text {th }}$ hour, in which enzyme activity value was $0.149 \mathrm{U} / \mathrm{mL}$ as a good potential to degradable chitin ability.

\section{Acknowledgements}

The authors would like to thank Fish Quarantine Station Laboratory Quality Control and Fisheries Product Security Class I Gorontalo Province of Indonesia, and Pharmaceutical Laboratory of Universitas Negeri Gorontalo support facility for this research.

\section{[References]}

[1] Bhattacharya D, Nagpure A, Gupta K R. Bacterial chitinases: Properties and potential. Critical Reviews in Biotechnology, 2008; 27(1): 21-28.

[2] Younes I, Bellaaj O G, Nasri R, Chaabouni M, Rinaudo M, Nasri M. Chitin and chitosan preparation from shrimp shells using optimized enzymatic deproteinization. Journal Process Chemistry, 2012; 47: 2032-2039.

[3] Arbia W, Arbia L, Adour L, Amrane A. Chitin extraction from crustaceanshells using biological methods. A Review Food Technol
Biotechnol, 2013; 51(1): 12-25.

[4] Purkan P, Baktir A, Sayyidah A R. Production of chitinase enzyme from aspergillus niger utilizing the blue swimmer crab's waste as inducer/ Produksi enzim kitinase dari Aspergillus niger menggunakan limbah cangkang rajungan sebagai induser. Journal Kimia Riset, 2016; 1(1): 34-38. (in Indonesian)

[5] Oh Y S, Shih L, Tzeng Y M, Wang S L. Protease produced by Pseudomonas aeruginosa K-187 and its application in the deproteinization of shrimp and crab shell waste. Enzyme and Microbial Technology, 2000 27(1-2): 3-10.

[6] Homaei A, Lavajoo F, Sariri R. Development of marine biotechnology as a resource for novel proteases and their role in modern biotechnology. International Journal of Biological Macromolecules, 2016; 88: 542-552.

[7] Sudin, Sulistijowati R, Harmain R M. Screening and growth pattern chitinolytic bacteria of blue swimmer crab's cell/ Penapisan dan pola pertumbuhan bakteri kitinolitik dari cangkang rajungan. Jambura Fish Processing Journal, 2020; 2(1): 36-45. (in Indonesian)

[8] Purkan P, Azizah B, Baktir A, Sumarsih S. Exploration of chitinolytic bacteria from organic waste: Isolation and characterization of chitinase enzyme. Journal of Molecular, 2014; 9(2): 129-133.

[9] Cappuccino J G, Sherman N. Microbiology a laboratory manual. Seven Edition. State University of New York, 2005; 143-203.

[10] Aditi F Y, Rahman S S, Hossain M D M. A study on the microbiological status of mineral drinking water. The Open Microbiology Journal 2017; 11: $31-34$.

[11] Patil R S, Ghormade V, Despande M V. Chitinolytic enzymes: An exploration. Journal Enzyme and Microbial Technology, 2000; 26: 473-483.

[12] Fukamizo T. Chitinolytic enzyme: Catalysis, substrate binding, and their application. Journal Current Protein \& Peptide Science, 2000; 1(1): 105-124.

[13] Orinda E, Puspita I D, Putra M P, Ustadi U, Lelana, I Y B. Chitinolytic enzyme activity of isolate SDI23 from petis and the activity of its partially purified enzyme in different $\mathrm{pH}$ and temperature (Aktivitas enzim pendegradasi kitin dari isolat SDI23 asal petis serta karakterisasi ph dan suhu dan aktivitas enzim hasil purivikasi parsial. Jurnal Perikanan). J. Fish. Sci, 2015; 17(2): 96-102. (in Indonesian)

[14] Zhu M M, He H J, Fan M T, Ma H J, Ren H W, Zeng J, et al. Application and optimization of solid-state fermentation process for enhancing polygalacturonase production by Penicillium expansum. Int J Agri \& Biol Eng, 2018; 11(6): 187-194.

[15] Setia I N, Suharjono. Chitinolytic assay and identification of bacteria Isolated from shrimp waste based on $16 \mathrm{~S}$ rDNA sequences. Advances in Microbiology, 2015; 5: 541-548.

[16] Hemraj V, Dikhsa S, Afneet G. A review commonly used biochemical test for bacteria. Journal of Life Science, 2013; 1(1): 1-7.

[17] Amano M M T, Enokimoto M, Yano T, Moe K K, Misawa N. Influence of $\mathrm{pH}$ of TSI medium on the detection of hydrogen sulfide production by campylobacter hyointestinalis. Journal Compilation, 2007; 44: 544-549.

[18] Cowan S C, Steel S. Manual for the identification of medical bacteria. Cambridge University Press Cambridge, London, 2003.

[19] Wang S L, Chang W T. Purification and characterization of two bifunctional chitinases/lysozymes extracellularly produced by Pseudomonas aeruginosa K-187 in a shrimp and crab shell powder medium. Applied and Environmental Microbiology, 1997: 63(2): 380-386.

[20] Thomson S E, Smith M, Wilkinson M C, Peek K. Identification and characterization of chitinase antigen from Pseudomonas aeruginosa strain 385. Applied and Environmental Microbiology, 2001; 67(9): 4001-4008. 